Dhaka Univ. J. Biol. Sci. 28(2): 131-138, 2019 (July)

\title{
PHYTOPLANKTON IN RELATION TO WATER QUALITY OF TANGUAR HAOR ECOSYSTEM, BANGLADESH: I. RAUAR STATION
}

\author{
Mohammad Azmal Hossain Bhuiyan*, S. A. M. Shariar Islam, Abu Kowser, \\ Md. Rasikul Islam, Shahina AKter Kakoly, KhandoKer AsaduZzaman ${ }^{1}$ \\ AND MONIRUZZAMAN KHONDKER \\ Department of Botany, University of Dhaka, Dhaka-1000, Bangladesh
}

Key words: Physical factors, Chemical factors, Phytoplankton standing crop, Chlorophyll a, Tanguar Haor, Rauar station

\begin{abstract}
The water quality at Rauar station of Tanguar Haor, Sunamganj was assessed studying phytoplankton and associated environmental variables. The environmental variables were monitored over a period of one year, collecting samples at two months interval between March, 2017 and March, 2018. Air temperature, rainfall, and humidity ranged from $22.6-32.1{ }^{\circ} \mathrm{C}, 48-76 \%$ and 8 $930 \mathrm{~mm}$, respectively. Air temperature showed a direct relationship with water temperature which varied from $22.4-31.0^{\circ} \mathrm{C}$ during the study period. The water transparency remained relatively constant throughout the year having a mean Secchi depth (Zs) value of $2.48 \mathrm{~m}$. Total dissolved solids (TDS), conductivity, and $\mathrm{pH}$ of the water ranged from $51-85 \mathrm{mg} \Lambda, 60-110 \mu \mathrm{S} / \mathrm{cm}$, and $7.2-9.7$, respectively. In December, because of a temperature fall, the dissolved oxygen (DO) concentration of the water reached its maximum value of $6.09 \mathrm{mg} 1$. In the rest of the period, the concentration remained between 2.44 and $4.80 \mathrm{mg} A$. The value of alkalinity ranged from $0.43-1.35$ meq $/$. Among the nutrients, soluble reactive phosphorus (SRP), soluble reactive silicate (SRS), and $\mathrm{NO}_{3}-\mathrm{N}$ ranged from $5.43-36.43 \mu \mathrm{g} \Lambda, 4-14.58 \mathrm{mg} \Lambda$, and $0.06-0.31 \mathrm{mg} \Lambda$, respectively. The concentration of $\mathrm{NH}_{4}{ }^{+}$ranged from $238-1230 \mu \mathrm{g} /$. The highest concentrations (905 and $1230 \mu \mathrm{g} /$ ) occurred between September and December, 2017. This might be attributed to the higher density of migratory birds during that period. The phytoplanktonic biomass expressed as chlorophyll-a (Chl-a) ranged from $1.35-8.45 \mu \mathrm{g} /$ while its degraded product phaeophytin concentration ranged from $0.08-3.5 \mu \mathrm{g} \Lambda$. The standing crop of phytoplankton ranged from $397-2480 \times$ $10^{3}$ individuals $\Lambda$ of haor water exhibiting its maximum abundance in September. This parameter showed a highly significant positive correlation with SRP. From the correlation analysis, the degradation of chl-a to phaeophytin was found to be temperature dependent. Considering the different physicochemical and biological water quality data, it could be said that the Tanguar Haor is still free from organic pollution. However, the range of soluble reactive phosphorus data $(5.43-36.43 \mu \mathrm{g} /$ ) show that the Haor has been passing a meso-eutrophic state.
\end{abstract}

\footnotetext{
*Author for correspondence: <bhuiyan.azmal@gmail.com>. ${ }^{1}$ Bangladesh Atomic Energy Commission, Savar, Dhaka -1349, Bangladesh.
} 


\section{Introduction}

Phytoplankton, the drifting microscopic photoautotrophic organisms, inhabiting the free water zone of almost all natural aquatic grounds, have been considered as a powerful biological tool for raising useful biomass for the ecosystem. In this context, their role in the pelagic grazing food chain is beyond question, because they are the beginner organism in the formation process of biological productivity and gaseous oxygen release $^{(1)}$. Haors of Bangladesh are well known and unique among all other freshwater ecosystems because of its vastness and rich biodiversity. Some of them contain a good number of individual bowl-shaped tectonic depressions, which via accumulation of rainwater during the rainy season takes a robust shape. The total surface area of the Haor of Bangladesh may go up to $24,500 \mathrm{~km}^{2(2)}$.

Tanguar Haor of Bangladesh, a Ramsar site, is very famous for its indigenous fish population, migratory birds, wild roses, wetland trees and many other valuable components of biodiversity ${ }^{(2-3)}$. Finding its role as an excellent sanctuary of aquatic lives, the Tanguar Haor has been declared as a natural ground for conservation to protect its species. Nearly 140 species of fishes are present in the Haor ${ }^{(3)}$. The annual fish production of the Haor has been estimated to be 5500 MT (4-5). The terminal edible biomass in the form of fish, is dependent on the pelagic grazing food chain where phytoplankton and the herbivorous zooplankton are the main actors. Very little information is available on the crop- and wetland plants, aquatic macrophytes, fishes and migratory birds of Tanguar Haor ecosystem ${ }^{(2-5)}$. Although Mamun ${ }^{(4)}$ reported the status of a few physicochemical water quality parameters of the Haor, there is no information on the qualitative and quantitative aspects of plankton, their key governing factors like the nutrients, and also the intensity of phytoplankton biomass as chl-a.

The present research has, therefore, been undertaken to study the community structure of pelagic plankton population and some of the key governing water quality factors at the study site, Rauar station of Tanguar Haor, Sunamganj.

\section{Materials and Methods}

The presently studied site Rauar station of Tanguar Haor is situated within $25^{\circ} 06^{\prime}$ $25^{\circ} 11^{\prime} \mathrm{N}$ and $91^{\circ} 01^{\prime}-91^{\circ} 06^{\prime} \mathrm{E}$ and approximately $2 \mathrm{~km}$ north of the Watch Tower of the Forest Department. Fig. 1 shows the geographical location of Rauar station of Tanguar Haor in Sunamganj district and the location of Sunamganj district in Bangladesh. Detailed information on the physiographic and morphometric features of Tanguar Haor is available in IUCN and Mamun ${ }^{(3,4)}$. The samples were collected mostly between 11:00 and 12:00 a.m. Air and water emperatures were measured using an alcoholic thermometer. A field multimeter (Hanna Multi Instruments, Code - HI 9813-6, SND0108196, Romania) was used to measure $\mathrm{pH}$, electrical conductivity and total dissolved solids (TDS) in situ. The depth of water was measured with the help of a graduated rope 
weighted at the end. A Secchi disc was used to measure the depth of transparency. Samples of dissolved oxygen were fixed in BOD bottles (Pyrex, clear glass-stoppered, 125 $\mathrm{ml}$ capacity) by adding the requisite amount of manganous sulfate and alkaline iodide solution. The bottles were carried to Dhaka for titration. An integrated water sample from the depth of $0-0.5 \mathrm{~m}$ was collected with the help of a Schindler's sampler. The water was carried to the laboratory in a black carboy (5 liter capacity). Plankton collection was carried out following two methods. Firstly, one liter of lake water from a suitable depth was poured into a glass bottle with Lugol's solution to obtain sediment of concentrated plankton. Another composite concentrated sample of plankton was obtained through sieving 100 liters of Haor water via plankton net (Nitex, mesh width of $55 \mu \mathrm{m})$. All the samples were transported to the laboratory keeping them in an ice box.

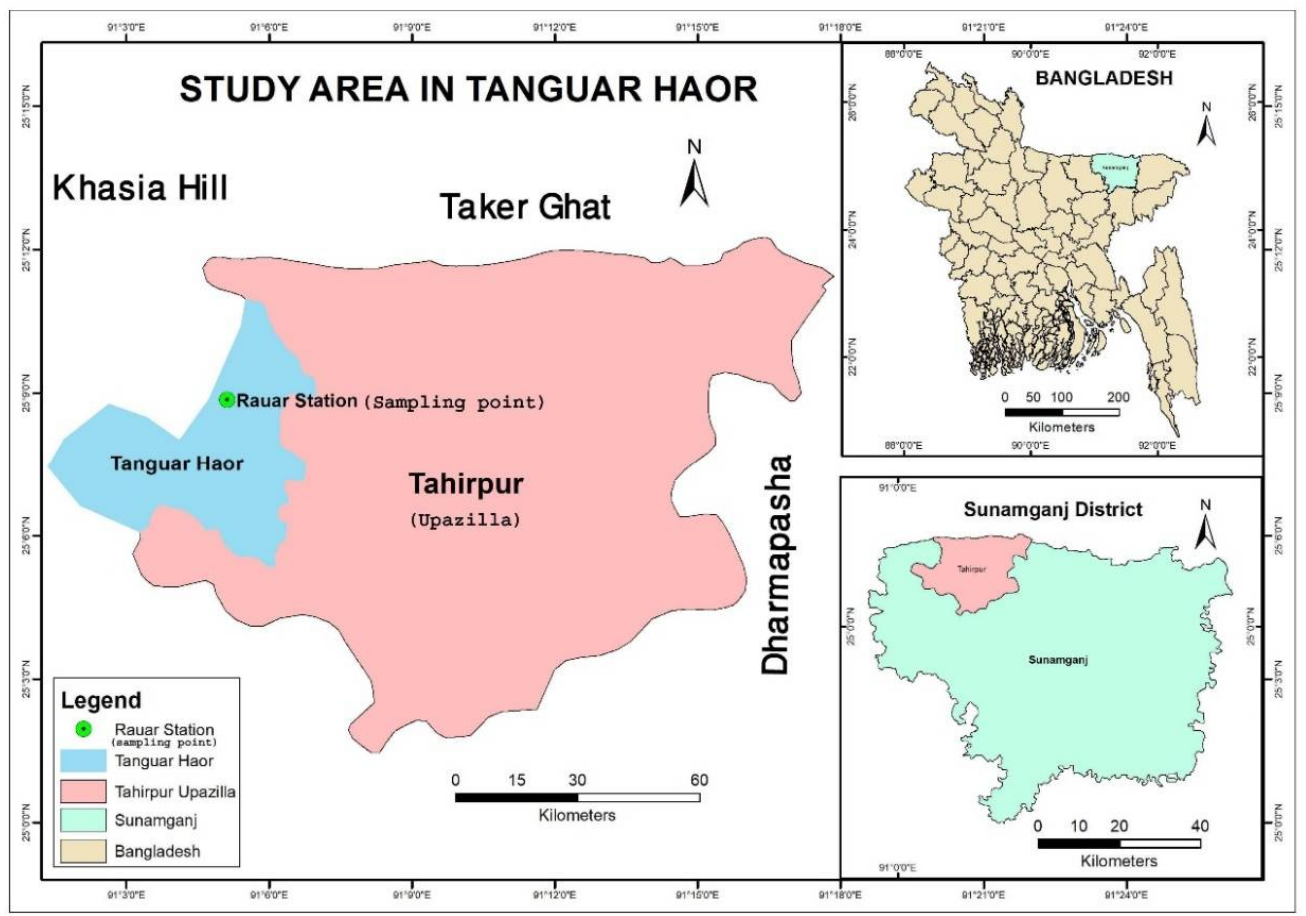

Fig. 1. Map of the sampling area situated at Tanguar Haor in Sunamganj district.

From the collected 5-liter water sample of the Haor, $300 \mathrm{ml}$ were filtered through a Whatman GF/C filter paper (circle dia. $48 \mathrm{~mm}$, pore diam. $1.4 \mu \mathrm{m}$ ) using a Sartorius filtration device. After filtration, the filter paper was used to extract chl-a and phaeopigment ${ }^{(6)}$. The filtrate was used to determine the concentration of soluble reactive phosphorus (SRP) and nitrate-nitrogen $\left(\mathrm{NO}_{3}-\mathrm{N}\right)$ following Murphey and Riley and Müller and Wiedeman (7-8), respectively. The same water was used to measure the concentration of soluble reactive silicate (SRS) following the method of Wetzel and 
Likens(9). Unfiltered water sample was used for measuring $\mathrm{NH}_{4}{ }^{+}$and alkalinity. Kjeldhal microdistillation method was used to determine the concentration of $\mathrm{NH}_{4}{ }^{+}$. Alkalinity was measured according to Mackereth et al.(10) and Wetzel and Likens ${ }^{(9)}$. All the measurements were done in triplicate and the mean value was recorded. The meteorological data for Sunamganj district was obtained from the website of Bangladesh Meteorological department, Dhaka, Bangladesh. Quantification of phytoplankton population from the collected concentrate was done by using a Helber Bacterial Counting Chamber (Thoma, UK). Pearson's correlation analysis was done to see the interrelationships among the water quality factors and the phytoplankton biomass of the studied station of Tanguar Haor.

\section{Results and Discussion}

Table 1 shows a total of 19 measured and collected variables from the Rauar station of Tanguar Haor over a period of one year (April, 2017 - March, 2018). The data were collected at two months interval because of the poor communication system. In April, 2017, the Haor was affected by an untimely flash flood event which inundated almost all of its cultivated rice fields. Some mortality of fishes, ducks, reptiles and other aquatic animals were seen instantly in the nearby Shanir Haor and the Hakaluki Haor of Moulvi Bazar district. The present research team was present in the Tanguar Haor just one day after the awful event occurred. The sampling was carried out in two places of the Tanguar Haor, namely at Watch Tower station and Rauar station. Closer to the Rauar station, only a few dead fishes were found. At that time, $582 \mathrm{~mm}$ rainfall was recorded with a humidity of $76 \%$. The air and water temperature were 31 and $29.8^{\circ} \mathrm{C}$, respectively. The water depth measured was $5.49 \mathrm{~m}$ with a transparency of $2.08 \mathrm{~m}$. No abnormality was observed in the study stations water quality data with respect to TDS, electrical conductivity, pH, DO, alkalinity, SRS, and nitrate nitrogen. However, the phosphorus concentration was 1.5 times higher than the annual mean. The water of the Haor experienced a high concentration of $\mathrm{NH}_{4}{ }^{+}$during the study period. The chl-a was recorded $8.45 \mu \mathrm{g} / \mathrm{l}$ supporting the phytoplankton standing crop of $1641 \times 10^{3}$ ind. $A$ in April, 2017.

The highest and lowest rainfalls were recorded in September, 2017 and January, 2018, respectively (Table 1). But, the highest humidity was recorded in July, 2017 and the lowest in February, 2018. The annual mean temperature for air was $0.34^{\circ} \mathrm{C}$ higher compared to annual mean temperature for water. The lowest water depth in the study station of Rauar was recorded in February, 2018 but the same was higher in the months of July, 2017 and September, 2017. The mean water depth of the study station was recorded $4.18 \mathrm{~m}$ (Table 1). The Secchi depth which indicates the transparency of water was almost uniform throughout the study period ranging from $2.08-3.05 \mathrm{~m}$ with a mean of $2.48 \pm 0.43 \mathrm{~m}$. The lower Secchi depth values indicate the study area is not loaded with 
biogenic and abiogenic suspended matters. The Secchi depth (Zs) values are supported by the data of TDS and electrical conductivity, the mean values of which were $64.17 \mathrm{mg} /$ and $81.67 \mu \mathrm{S} / \mathrm{cm}$, respectively (Table 1). The $\mathrm{pH}$ of the water was high in December, 2017 and January, 2018 (9.4 and 9.7, respectively). But at other times, it ranged from 7.2 - 7.9. The mean $\mathrm{pH}$ showed almost an alkaline condition of the Haor. The DO concentration ranged from $2.44-6.09 \mathrm{mg} /$ with an annual mean of $3.77 \mathrm{mg} /$. A drop in air and water temperature in December, 2017 resulted in an increase $(6.09 \mathrm{mg} \Lambda$ ) in DO of water (Table 1). Free $\mathrm{CO}_{2}$ concentration in the Haor water is relatively low; on the contrary, an alkalinity range of $0.34-1.35 \mathrm{meq} \Lambda$ indicates the source of carbon for assimilation by

Table 1. Environmental, physicochemical and biological variables measured at Rauar station of Tanguar Haor, Sunamganj district.

\begin{tabular}{|c|c|c|c|c|c|c|c|c|c|c|}
\hline \multicolumn{2}{|l|}{ Date } & $\begin{array}{l}\text { Rainfall } \\
(\mathrm{mm})\end{array}$ & $\begin{array}{l}\text { Humidity } \\
(\%)\end{array}$ & $\begin{array}{l}\text { Air temp. } \\
\left({ }^{\circ} \mathrm{C}\right)\end{array}$ & $\begin{array}{l}\text { Water } \\
\text { temp. }\left({ }^{\circ} \mathrm{C}\right)\end{array}$ & $\begin{array}{l} \\
(\mathrm{m})\end{array}$ & $\begin{array}{l}\text { Zs } \\
(\mathrm{m})\end{array}$ & $\begin{array}{l}\text { TDS } \\
(\mathrm{mg} \Lambda)\end{array}$ & $\begin{array}{l}\text { Cond. } \\
(\mu S / \mathrm{cm})\end{array}$ & $\mathrm{pH}$ \\
\hline \multicolumn{2}{|c|}{22 Apr., 2017} & 582 & 76 & 31.0 & 29.8 & 5.49 & 2.08 & 61 & 80 & 7.2 \\
\hline \multicolumn{2}{|c|}{09 Jul., 2017} & 895 & 85 & 23.9 & 22.4 & 6.09 & 2.28 & 62 & 80 & 7.5 \\
\hline \multicolumn{2}{|c|}{30 Sept., 2017} & 930 & 78 & 27.0 & 28.6 & 6.09 & 3.04 & 85 & 110 & 7.8 \\
\hline \multicolumn{2}{|c|}{09 Dec., 2017} & 75 & 67 & 22.6 & 22.7 & 3.35 & 3.05 & 51 & 60 & 9.4 \\
\hline \multicolumn{2}{|c|}{22 Jan., 2017} & 8 & 58 & 23.4 & 23.5 & 2.28 & 2.28 & 55 & 70 & 9.7 \\
\hline \multicolumn{2}{|c|}{25 Mar., 2018} & 71 & 48 & 32.1 & 31.0 & 1.80 & 2.20 & 71 & 90 & 7.9 \\
\hline \multicolumn{2}{|c|}{ Annual mean } & 426.71 & 68.66 & 26.67 & 26.33 & 4.18 & 2.48 & 64.17 & 81.67 & 8.3 \\
\hline \multicolumn{2}{|l|}{$\mathrm{SD} \pm$} & 429.23 & 13.79 & 4.08 & 3.89 & 1.95 & 0.43 & 12.27 & 17.22 & 1.04 \\
\hline \multicolumn{11}{|c|}{ Table contd. right side } \\
\hline $\begin{array}{l}\mathrm{DO} \\
(\mathrm{mg} /) \\
\end{array}$ & $\begin{array}{l}\mathrm{CO}_{2} \\
(\mathrm{mg} \Lambda)\end{array}$ & $\begin{array}{l}\text { Alkal. } \\
\text { (meq } 1)\end{array}$ & $\begin{array}{l}\text { SRP } \\
(\mu \mathrm{g} / \mathrm{l})\end{array}$ & $\begin{array}{l}\text { SRS } \\
(\mathrm{mg} /)\end{array}$ & $\begin{array}{l}\mathrm{NO}_{3}-\mathrm{N} \\
(\mathrm{mg} \Lambda)\end{array}$ & $\begin{array}{l}\mathrm{NH}_{4}^{+} \\
(\mu \mathrm{g} \Lambda)\end{array}$ & $\begin{array}{l}\text { Chl-a } \\
(\mu \mathrm{g} / \mathrm{l})\end{array}$ & $\begin{array}{l}\text { Phaeo. } \\
(\mu \mathrm{g} / \mathrm{l})\end{array}$ & \multicolumn{2}{|c|}{$\begin{array}{l}\text { Total PP } \\
\times 10^{3} \text { ind. } 1\end{array}$} \\
\hline 3.04 & 0.10 & 0.34 & 25.72 & 11.55 & 0.19 & 820 & 8.45 & 3.12 & 1641 & \\
\hline 3.04 & 0.08 & 0.53 & 5.43 & 7.38 & 0.23 & 550 & 7.18 & 1.56 & 397 & \\
\hline 2.44 & 0.10 & 1.35 & 36.43 & 8.24 & 0.31 & 905 & 4.6 & 2.48 & 2480 & \\
\hline 6.09 & 0.03 & 1.35 & 8.09 & 11.53 & 0.06 & 1230 & 1.35 & 0.08 & 920 & \\
\hline 4.80 & 0.04 & 0.67 & 11.19 & 4.00 & 0.14 & 686 & 2.95 & 0.91 & 655 & \\
\hline 3.20 & 0.96 & 1.03 & 10.95 & 14.58 & 0.14 & 686 & 7.18 & 3.5 & 1185 & \\
\hline 3.77 & 0.22 & 0.88 & 16.30 & 9.55 & 0.18 & 813 & 5.28 & 1.94 & - & \\
\hline 1.39 & 0.36 & 0.43 & 12.11 & 3.75 & 0.08 & 238 & 2.78 & 1.32 & - & \\
\hline
\end{tabular}

phytoplankton as bicarbonate ${ }^{(11)}$. A number of green algal species prefer carbonate to grow; consequently, the phytoplankton community of Tanguar Haor at Rauar station is dominated by green algae (49\%). Soluble reactive phosphorus concentration ranged from $5.43-36.43 \mu \mathrm{g} / \mathrm{l}$ indicating a mesotrophic condition of the water ${ }^{(12)}$. The concentration of soluble reactive silicate ranged from $4.0-14.58 \mathrm{mg} /$ which is also lower than river Gomti and Buriganga of Bangladesh ${ }^{(13)}$. The $\mathrm{NO}_{3}{ }^{-}$concentration was found to vary between 0.06 
and $0.31 \mathrm{mg} \Lambda$ showing its highest presence in September and lowest in December. The mean $\mathrm{NO}_{3}$ - concentration followed the trend of the SRP concentration. A relatively high concentration of $\mathrm{NH}_{4}{ }^{+}$was obtained in the Haor water (Table 1). The mean value was 813 $\mu \mathrm{g} /$ on an annual scale. The highest value of $\mathrm{NH}_{4}{ }^{+}(1230 \mu \mathrm{g} \Lambda)$ was recorded in the month of December, 2017. This could be attributed to the addition of the bird drops; the studied station is visited by a higher number of birds (13160 individuals) compared to most of the beels of the Tanguar Haor. Only the beel Lechuamara is frequented by a higher number of birds (13294 individuals) than the Rauar station ${ }^{(3)}$. Decomposing bird drops and submerged vegetation could be the main sources of ammonia in the Tanguar Haor ecosystem.

Phytoplankton biomass as chl-a ranged from $1.35-8.45 \mu \mathrm{g} / \mathrm{l}$, showing its highest concentration in April, 2017 and lowest in December, 2017. The mean chl-a $5.28 \mu \mathrm{g} / \mathrm{l}$ is somewhat lower than the concentration usually obtained in the mesotrophic water body of Bangladesh (12). The concentration of the chl-a degraded product phaeophytin also showed a corresponding low value. Annual mean calculated for phaeophytin was 1.94 $\mu \mathrm{g} / \mathrm{l}$. Even though phytoplankton biomass as chl-a is a good indicator of production processes of almost all the water bodies, yet it is seldom studied in the habitats of Bangladesh.

Table 2. A comparison of some water quality variables from different wetlands of Bangladesh (data represent mean values).

\begin{tabular}{|c|c|c|c|c|c|}
\hline \multirow{2}{*}{$\begin{array}{l}\text { Parameters } \\
\text { (units) }\end{array}$} & \multicolumn{5}{|c|}{ Wetlands } \\
\hline & $\begin{array}{l}\text { Khilkhet } \\
\text { Beel }^{(14)}\end{array}$ & Joysagar ${ }^{(15)}$ & $\begin{array}{l}\text { Hakaluki } \\
\text { Haor }^{(16)}\end{array}$ & $\begin{array}{l}\text { Tanguar } \\
\text { Haor }^{(4)}\end{array}$ & $\begin{array}{l}\text { Tanguar Haor } \\
\text { (present study) }\end{array}$ \\
\hline Water temp. $\left({ }^{\circ} \mathrm{C}\right)$ & 30.56 & 27.4 & 26.8 & 28.0 & 26.33 \\
\hline Secchi depth (m) & - & - & 0.43 & - & 2.48 \\
\hline $\operatorname{TDS}(\mathrm{mg} \Lambda)$ & - & - & 68.68 & 846 & 64.17 \\
\hline Cond. $(\mu \mathrm{S} / \mathrm{cm})$ & 121.67 & 109.2 & 141.2 & 1294 & 81.67 \\
\hline $\mathrm{pH}$ & 7.06 & 7.4 & 6.44 & 7.32 & 8.3 \\
\hline $\mathrm{DO}(\mathrm{mg} \Lambda)$ & 7.83 & - & 4.9 & 5.03 & 3.77 \\
\hline Alkal. (meq $\Lambda)$ & 0.53 & 0.66 & 0.46 & - & 0.88 \\
\hline $\mathrm{SRP}(\mu \mathrm{g} / \mathrm{l})$ & 128.74 & 79.87 & 6221 & - & 16.3 \\
\hline SRS (mg 1$)$ & 8.86 & 11.43 & - & - & 9.55 \\
\hline $\mathrm{NO}_{3}-\mathrm{N}(\mu \mathrm{g} / \mathrm{l})$ & 115.78 & 97.7 & 6220 & - & 180 \\
\hline $\mathrm{NH}_{4}{ }^{+}(\mathrm{mg} /)$ & - & - & - & - & 813 \\
\hline Chl-a $(\mu \mathrm{g} / \mathrm{l})$ & 20.53 & 174.1 & - & - & 5.28 \\
\hline Phaeo. $(\mu \mathrm{g} / \mathrm{l})$ & 11.58 & - & - & - & 1.94 \\
\hline
\end{tabular}

Table 2 presents a comparison of several water quality parameters from Hakaluki and Tanguar Haor and two other water bodies possessing wetland characteristics, 
namely Khilkhet Beel of Dhaka and Joysagar of Sirajganj district along with the results of the present investigation. From Table 2, it is evident that the mean water temperature recorded in the present investigation for Tanguar Haor is quite consistent with Joysagar and Hakaluki Haor. The water temperature of Khilkhet Beel ${ }^{(11)}$ and Tanguar Haor ${ }^{(4)}$ are a little bit higher. This is because these water bodies were sampled during summer. Secchi depth for Hakaluki $(0.43 \mathrm{~m})$ shows that it is six times less transparent compared to the water of Tanguar Haor (Table 2). However, the TDS content of both the studied Haors is almost similar (Table 2). The electrical conductivity of water for all the studied wetlands are quite consistent with each other except the measurement carried out by Mamun ${ }^{(4)}$ for Tanguar Haor. It is not clear as to why the TDS and electrical conductivity are so high ( $13 \times$ for the former and $16 \times$ for the latter parameter) for Tanguar Haor. A relatively high transparency value (Secchi depth $2.48 \mathrm{~m}$ ) measured in the presently studied station of Tanguar Haor is quite consistent with the values measured for TDS, conductivity, DO, SRP and chl-a. Low chl-a signifies a low phytoplankton standing crop. This phenomenon is because of the low concentration of SRP, SRS, and TDS. Lower phytoplankton biomass in Tanguar Haor might have resulted low DO and conductivity (Table 2).

Correlation studies were done among 17 water quality, environmental and biological variables. The result of significant relationships at 0.01 level (2-tailed) and 0.05 level (2-tailed) has been included in Table 3.

Table 3. Results of significant correlations among the studied variables.

\begin{tabular}{llll}
\hline Variables & $\begin{array}{l}\text { Levels of } \\
\text { significance }\end{array}$ & Variables & $\begin{array}{l}\text { Levels of } \\
\text { significance }\end{array}$ \\
\hline AT vs WT & $0.958^{* *}$ & DO vs NO & $-0.869^{*}$ \\
AT vs phaeo. & $0.952^{*}$ & DO vs phaeo. & $0.824^{*}$ \\
WT vs phaeo. & $0.922^{* *}$ & SRP vs plank. & $0.957^{* *}$ \\
Zs vs alkal. & $0.870^{*}$ & $\mathrm{NO}_{3}$ vs cond. & $0.855^{*}$ \\
TDS vs cond. & $0.992^{* *}$ & Chl-a vs pH & $-0.900^{*}$ \\
Cond. vs DO & $0.857^{*}$ & Chl-a vs phaeo & $0.832^{*}$ \\
DO vs pH & $0.870^{*}$ & & \\
\hline
\end{tabular}

$\mathrm{AT}$, air temperature; WT, water temperature; phaeo., phaeopigment; Zs, Secchi depth; alkal., alkalinity; TDS, total dissolved solids; cond., conductivity; DO, dissolved oxygen; SRP, soluble reactive phosphorus; plank., plankton; chl-a, chlorophyll-a. ${ }^{* *}$, correlation is significant at the 0.01 level (2-tailed); *, correlation is significant at the 0.05 level (2-tailed).

DO showed correlations with most of the variables. It showed a negative correlation with $\mathrm{NO}_{3}-\mathrm{N}$, but positive with conductivity, $\mathrm{pH}$ and phaeopigment. Phaeopigment also showed positive correlation with water temperature. The density of phytoplankton in the studied station of Tanguar Haor showed highly significant positive correlation with SRP. It means the system is limited by the supply of phosphorus. The concentration of SRP 
and chl-a show that the water body has been passing its meso-eutrophic state in terms of trophic state. Therefore, even though the high concentration of ammonia is a recurring phenomenon in the study area, the Haor cannot be termed as polluted as such.

\section{References}

1. Reynolds CS 1984. The ecology of freshwater phytoplankton. Cambridge Univ. Press. Cambridge. pp. 384.

2. Khan MS, Haq E, Huq S, Rahman AA, Rashid SMA and Ahmed H (Eds) 1994. Wetlands of Bangladesh. BCAS and Nature Conservation Movement. Dhaka, Bangladesh. pp. 91.

3. IUCN 2011. Wildlife of Tanguar Haor. Sobhan I and Karim AFMR EdS, IUCN, Bangladesh Country Office, Final Report. pp. 120.

4. Mamun SA, Roy S, Rahaman MS, Jahan and Islam MS 2013. Status of fisheries resources and water quality of Tanguar Haor. J. Env. Sci. Nat. Res. 6(1): 103-106.

5. Ahmed M 2012. Community-led framework for estimation of sustainable exploitation level of fish and reeds in Tanguar Haor. Community-based sustainable management of Tanguar Haor Project-II, IUCN, SDC (Swiss Agency for Development and Cooperation). pp. 1-30.

6. Marker AFH, Nusch EA, Rai H and Riemann B 1980. The measurement of photosynthetic pigments in freshwaters and standardization of methods: conclusions and recommendations. Arch. Hydrobio. Beih. Ergebn. Limnol. 14: 91-106.

7. Murphy J and Riley RP 1962. A modified simple solution method for the determination of phosphate in natural water. Anal. Chim. Acta. 27: 31-36.

8. Müller R and Wiedemann F 1955. Die Bestimmung des Nitrates in Wasser. Jahrbuch fur Wasserchemcie und Wasserreinigungtech. 12: 247-271.

9. Wetzel RG and Likens GE 1979. Limnological analysis. WB Saunders Co., Philadelphia. pp. 357.

10. Mackereth, F. J. H., Heren, J. and Talling, J. F. 1978. Water analysis. Some revised methods for Limnologists. Freshwater Biol. Assoc. Sci. Publ. No. 36. pp. 119.

11. Ruttner F 1975. Fundamentals of limnology. 3rd edn. Translated from German by Frey DG and Fry FEG, Univ. Toronto Press, Toronto, pp. 307.

12. Khondker M and Kabir MA 1995. Phytoplankton primary production in a mesotrophic pond in sub-tropical climate. Hydrobiologia 304: 39-47.

13. Bhuiyan MAH and Khondker M 2018. Water quality and potamoplankton of the river Buriganga and Gomti: A comparison. Dhaka Univ. J. Biol. Sci. 27(2): 191-200.

14. Islam AKM Nurul, Khondker M, Begum A and Akhter N 1992. Hydrobiological studies in two habitats at Dhaka. J. Asiatic Soc. Bangladesh, Sci. 18: 47-52.

15. Nahar K, Khondker M and Sultana M 2010. Seasonal succession and diversity of benthic diatom of two wetland ecosystems of Bangladesh. Bangladesh J. Bot. 39(1): 29-36.

16. Islam MT, Rahman MM and Mahmud H 2014. Physicochemical attributes of water of Hakaluki Haor, Sylhet, Bangladesh. Jahangirnagar University J. Biol. Sci. 3(2): 67-72. 